\title{
Familial Mediterranean Fever in Iran: A Report from FMF Registration Center
}

\author{
Farhad Salehzadeh \\ Pediatric Department, Bouali Children's Hospital, Ardabil University of Medical Sciences (ARUMS), \\ No. 105 Shahrak Azadi Azarbyjan Street, Ardabil 56157, Iran
}

Correspondence should be addressed to Farhad Salehzadeh; salehzadeh_f@yahoo.com

Received 10 June 2015; Revised 14 August 2015; Accepted 18 August 2015

Academic Editor: Ruben Burgos-Vargas

Copyright (c) 2015 Farhad Salehzadeh. This is an open access article distributed under the Creative Commons Attribution License, which permits unrestricted use, distribution, and reproduction in any medium, provided the original work is properly cited.

Background. Familial Mediterranean fever (FMF) is a periodic AR autoinflammatory disorder. This comprehensive study describes FMF in Iran as a country near Mediterranean area. Materials and Methods. From the country FMF registration center 403 patients according to Tel-Hashomer criteria enrolled this study, 239 patients had MEFV gene mutations analyses. Data, if needed, was analyzed by SPSS v20. Results. 175 patients (43.4\%) were female and 228 patients (56.6\%) were male. The mean age was 21.3 years. Abdominal pain was in $93.3 \%$ patients and $88.1 \%$ had fever. Abdominal pain was the main complaint of patients in (49.6\%). The mean interval between attacks was $36.5 \pm 29.6$ days and the mean duration of every episodes was $43.3 \pm 34.5$ hours. $15.1 \%$ of patients had positive family history and $12.7 \%$ had previous surgery; in $52.3 \%$ of patients delay in diagnosis was more than three years. 12 common MEFV gene mutations were analyzed, $21.33 \%$ were without mutations, $39.7 \%$ had compound heterozygote, $25.52 \%$ showed heterozygous, and $13.38 \%$ showed homozygous results. The most common compound genotype was M694V-V726A (\% 10.46) and in alleles M694V (\% 20.9) and V726A (\% 12.7) were the most frequent mutations, respectively. Conclusion. M694V was the most common mutation, and the most common compound genotype was M694V-V726A. Our genotype results are similar to Arabs and in some way to Armenians, erysipelas-like skin lesions are not common in this area, and clinical criteria are the preferred methods in diagnosis of FMF.

\section{Introduction}

Familial Mediterranean fever (FMF) is an autosomal recessive inherited disorder $[1,2]$. It is common among Mediterranean populations (Jews, Arabs, Turks, and Armenians) [3]. FMF is characterized by recurrent fever and inflammation of serous membranes, leading to abdominal pain, joint pain, and chest pain.

The most important complication of FMF is amyloidosis, which eventually leads to kidney failure [4]. Symptoms of the disease usually occur during the first decade of life in more than $80 \%$ of patients [5]. The highest prevalence of the disease among the "Sephardic Jews" and the Armenians has been reported [6].

FMF seems to be more common in males with the prevalence rate 1.5 to 2 times [7]. The disease frequency at an early age and infants is low [8]. In Middle East its prevalence is one in 2,000 to one in 100, according to different studies [9].

MEFV gene, responsible for the disease, located on chromosome $16 \mathrm{P}$ (13.3) codes synthesis of a protein called pyrin [10].

Ongoing and recurrent inflammation leads to amyloid production and deposition of it in vital organs, especially the kidneys [7].

More than 300 known mutations in the MEFV gene have been reported [11].

The appearance of homozygous mutations was significantly associated with severe clinical presentations of the FMF $[10,12]$. This mutation is related to disease onset at an early age and more prevalence of arthritis and progression to amyloidosis [13].

M680I is common among Armenians and Turks and is associated with more severe form of the relapsing fever 
in early childhood which may be the only presentation of familial Mediterranean fever [2]. In $90 \%$ of the patients disease is begun before 20 years of age [9].

Approximately $50 \%$ of patients experience joint pain during the attacks. The pain is usually limited to one joint at a time [9]. Typical FMF arthritis is usually benign and self-limited acute monoarthritis [14]. The most commonly involved joints include hip, knees, elbows, and wrists [14-16].

Protracted febrile myalgia syndrome (PFMS) is presented with prolonged fever and an increase of ESR and leukocytosis. It usually takes 6 to 8 weeks and respond to treatment with prednisolone $[17,18]$. The M694V mutation associated with a higher incidence of PFMS [19].

About $45 \%$ of patients have experienced pleural attacks. Pleural attacks are sudden, unilateral attacks that subsides within 48 hours [20].

Pleuritis prevalence has been between $20 \%$ and $80 \%$ in different studies [7]. Pericarditis and tamponade, myocarditis, and cardiac amyloidosis are the most common cardiovascular presentation in FMF [21, 22].

The nonamyloidosis renal involvement has been reported in $22 \%$ of patients and include temporary or permanent hematuria, proteinuria, acute pyelonephritis, interstitial nephritis, and glomerulonephritis due to coexisting disease $[23,24]$.

The classic skin lesion is periodic erysipelas-like skin rash. It is a pathognomonic finding in FMF which usually fades within 72-48 hours; fever and leukocytosis may accompany the rash. The incidence of rash is $3 \%-46 \%$ and is usually associated with M694V mutation [15]; sometimes erysipelas rash and fever are the only sign of FMF [25].

Acute scrotal swelling, a painful inflammation of the testis, in a small percentage of children with FMF, has been reported. In Arabs it has been described as a common feature of FMF [26]. Infertility in patients with FMF has no difference with the general population [27, 28]. Recurrent aseptic meningitis can rarely occur in FMF; these attacks are prevented after treatment with colchicine [29].

Familial Mediterranean fever may be associated with different systemic inflammatory diseases including Behcet, polyarteritis nodosa and Henoch-Schonlein purpura [30], spondyloarthropathy [2], multiple sclerosis [31, 32], and inflammatory bowel diseases $[33,34]$.

On the basis of clinical findings Tel-Hashomer criteria have been described to be FMF diagnosis [11, 35].

There is no specific standard laboratory test for FMF; nowadays compound MEFV gene mutations in hemo- or heterozygote forms confirm the diagnosis of FMF [36].

\section{Materials and Methods}

This is a case series study. This study included all patients with familial Mediterranean fever in FMF Clinic at Bouali Hospital and FMF Registration Center in Iran (http://www.fmfiran.ir/). 422 patients were enrolled in this study; all patients had FMF according to Tel-Hashomer criteria and/or at least two MEFV gene mutations. 19 patients were excluded because of unavailability and study was conducted on 403 patients with FMF. Common MEFV genes
TABLE 1: Clinical findings in our patients.

\begin{tabular}{lcc}
\hline Clinical symptoms & Number of patients & Percent \\
\hline Abdominal pain & 376 & 93.3 \\
Fever & 355 & 88.1 \\
Fatigue & 282 & 70 \\
Anorexia & 258 & 64 \\
Nausea & 139 & 34.5 \\
Myalgia & 118 & 29.3 \\
Vomiting & 107 & 26.6 \\
Arthralgia & 103 & 25.6 \\
Constipation & 96 & 23.8 \\
Chest Pain & 72 & 17.9 \\
Diarrhea & 69 & 17.1 \\
Vertigo & 42 & 10.4 \\
Dysuria & 41 & 10.2 \\
Headache & 36 & 8.9 \\
Arthritis & 31 & 7.7 \\
\hline
\end{tabular}

mutations (E148Q, P369S, F479L, M680I (G/C), M680I (G/A), I692del, M694V, M694I, K695R, V726A, A744S, and $\mathrm{R} 761 \mathrm{H}$ ) have been analyzed in 239 patient. Descriptive analysis was used to analyze data by V20 SPSS.

\section{Results}

The mean age of patients was 21.03 years. The youngest patient was 1.5 years old and the oldest one was 76 years old. The average age of onset of symptoms was 9.75 years and the first decade of life was the most common age range which was in 128 patients (31.8\%).

228 patients $(56.6 \%)$ were males and 333 patients were living in urban area. The main complaint of patients was abdominal pain, in 200 cases (49.6\%), and abdominal pain plus fever in $67(16.6 \%)$ patients was the second main complaint. Table 1 shows the main symptoms of patients.

Interval between attacks was $36.5 \pm 29.6$ days and the mean duration of each episode was $43.3 \pm 34.5$ hours.

239 patients had MEFV gene mutations analysis; Table 2 shows these results. 51 patients $(21.33 \%)$ had no mutations in this analysis.

The most common homozygous mutation was M694VM694V (7.1\%) and compound heterozygous mutation was M694V-V726A (10.46\%) and monoheterozygous mutation was E148Q (8.7\%).

Genotype-phenotype correlation has been shown in Table 3.

With regard to the time between onset of symptoms and diagnosis of FMF in 207 patients (52.3\%) this period was more than 3 years.

Colchicine administration in $89.9 \%$ patients had good results and in $7.2 \%$ patients showed moderate response while $2.9 \%$ patients had poor response. $13.2 \%$ of patients used drug irregularly. The most common colchicine side effect was diarrhea in $4.7 \%$ of patients.

In our series two cases had erysipelas-like skin rash with negative MEFV results which indicate the rarity of this feature 
TABLE 2: Results of MEFV genes mutations and different allele's analysis.

\begin{tabular}{|c|c|c|c|}
\hline Mutation & Genotype & Percent & Number \\
\hline \multirow{7}{*}{$\begin{array}{l}\text { Heterozygote } \\
N=61(25.52 \%)\end{array}$} & E148Q & 8.7 & 21 \\
\hline & M694V & 8.36 & 20 \\
\hline & V726A & 2.5 & 6 \\
\hline & A744S & 1.7 & 4 \\
\hline & M680I & 2.1 & 5 \\
\hline & P396S & 1.2 & 3 \\
\hline & $\mathrm{R} 761 \mathrm{H}$ & 0.84 & 2 \\
\hline \multirow{7}{*}{$\begin{array}{l}\text { Homozygote } \\
N=32(13.38 \%)\end{array}$} & M694V-M694V & 7.1 & 17 \\
\hline & M680I-M680I & 2.92 & 7 \\
\hline & E148Q-E148Q & 0.84 & 2 \\
\hline & M694I-M694I & 0.84 & 2 \\
\hline & V726A-V726A & 0.84 & 2 \\
\hline & P396S-P396S & 0.42 & 1 \\
\hline & R761H-R761H & 0.42 & 1 \\
\hline \multirow{18}{*}{$\begin{array}{l}\text { Compound } \\
\text { heterozygote } \\
N=95(39.7 \%)\end{array}$} & M694V-V726A & 10.46 & 25 \\
\hline & E148Q-M694V & 2.96 & 7 \\
\hline & M680I-V726A & 6.27 & 15 \\
\hline & R761H-M694V & 2.5 & 6 \\
\hline & M680I-M694V & 2.5 & 6 \\
\hline & R761H-E148Q & 0.42 & 1 \\
\hline & V726A-R761H & 2.5 & 6 \\
\hline & M694V-M694I & 0.84 & 2 \\
\hline & M680I-R761H & 2.5 & 6 \\
\hline & M680I-E148Q & 0.84 & 2 \\
\hline & E148Q-P396S & 2.96 & 7 \\
\hline & A744S-R761H & 0.42 & 1 \\
\hline & E148Q-V726A & 1.69 & 4 \\
\hline & K694R-V726A & 0.42 & 1 \\
\hline & E148Q-A744S & 0.42 & 1 \\
\hline & E148Q-M694I & 1.27 & 3 \\
\hline & M694I-M680I & 0.42 & 1 \\
\hline & F497L-E148Q & 0.42 & 1 \\
\hline $\begin{array}{l}\text { Patient with no } \\
\text { identified mutation } \\
N=51(21.33 \%)\end{array}$ & & 21.33 & 50 \\
\hline
\end{tabular}

in this area. We had two siblings with idiopathic hepatitis and massive ascites who were homozygous for M694V gene.

\section{Discussion}

Many studies have shown male preponderance in FMF [38, 40, 41]. In Sackesen et al. [52] and Dunder et al. [37] the average age of onset was second decade of life. In Yilmaz study [38] $90 \%$ of patients had fever, $95 \%$ of patients had abdominal pain, and $19 \%$ of patients had erroneous appendectomy. In a study on 229 patients, 115 were females and $68 \%$ of patients had MEFV gene mutations. High fever in $94 \%$ of patients and abdominal pain in $83 \%$ were the main symptoms [53].
TABLE 3: Genotype and phenotype correlations.

\begin{tabular}{|c|c|c|}
\hline & $\begin{array}{l}\text { Common } \\
\text { combined } \\
\text { mutations }\end{array}$ & $\begin{array}{l}\text { The most } \\
\text { common alleles }\end{array}$ \\
\hline $\begin{array}{l}\text { Abdominal pain } \\
N=120\end{array}$ & $\begin{array}{l}\text { V726A-M694V } \\
N=159(12.5 \%)\end{array}$ & $\begin{array}{c}\mathrm{M} 694 \mathrm{~V} \\
N=47(19.6 \%)\end{array}$ \\
\hline $\begin{array}{l}\text { Fever } \\
N=36 \\
\end{array}$ & $\begin{array}{l}\text { V726A-M680I } \\
N=5(13.9 \%) \\
\end{array}$ & $\begin{array}{c}\mathrm{M} 694 \mathrm{~V} \\
N=14(19.4 \%) \\
\end{array}$ \\
\hline $\begin{array}{l}\text { Chest pain } \\
N=12\end{array}$ & $\begin{array}{c}\text { V726A-M694V } \\
\text { and } \\
\text { R761H-M694V } \\
N=2(16.7 \%)\end{array}$ & $\begin{array}{c}\mathrm{M} 694 \mathrm{~V} \\
N=7(29.2 \%)\end{array}$ \\
\hline $\begin{array}{l}\text { Joint pain } \\
N=6\end{array}$ & $\begin{array}{c}\mathrm{M} 694 \mathrm{~V}-\mathrm{M} 694 \mathrm{~V} \\
N=2(33.3 \%)\end{array}$ & $\begin{array}{c}\mathrm{M} 694 \mathrm{~V} \\
N=6(50 \%)\end{array}$ \\
\hline $\begin{array}{l}\text { Patients with } \\
\text { positive family } \\
\text { history } \\
N=38\end{array}$ & $\begin{array}{l}\text { V726A-M694V } \\
N=10(26.3 \%)\end{array}$ & $\begin{array}{c}\mathrm{M} 694 \mathrm{~V} \\
N=25(32.9 \%)\end{array}$ \\
\hline $\begin{array}{l}\text { Age at FMF onset } \\
1 \text { to } 10 \text { years } \\
N=156\end{array}$ & $\begin{array}{c}\text { M694V-M694V } \\
N=11(7.1 \%)\end{array}$ & $\begin{array}{c}\mathrm{M} 694 \mathrm{~V} \\
N=58(18.1 \%)\end{array}$ \\
\hline $\begin{array}{l}\text { Age at FMF onset } \\
10 \text { to } 20 \text { years } \\
N=41\end{array}$ & $\begin{array}{l}\text { V726A-M694V } \\
N=5(12.2 \%)\end{array}$ & $\begin{array}{c}\mathrm{M} 694 \mathrm{~V} \\
N=19(23.2 \%)\end{array}$ \\
\hline $\begin{array}{l}\text { Age at FMF onset } \\
\text { after } 20 \text { years } \\
N=42\end{array}$ & $\begin{array}{l}\text { V726A-M694V } \\
N=10(23.8 \%)\end{array}$ & $\begin{array}{c}\mathrm{M} 694 \mathrm{~V} \\
N=25(29.8 \%)\end{array}$ \\
\hline $\begin{array}{l}\text { Male } \\
N=134 \\
\end{array}$ & $\begin{array}{l}\text { V726A-M694V } \\
N=17(12.7 \%) \\
\end{array}$ & $\begin{array}{c}\mathrm{M} 694 \mathrm{~V} \\
N=49(18.3 \%) \\
\end{array}$ \\
\hline $\begin{array}{l}\text { Female } \\
N=106\end{array}$ & $\begin{array}{l}\text { M694V-M694V } \\
N=11(10.4 \%)\end{array}$ & $\begin{array}{c}\mathrm{M} 694 \mathrm{~V} \\
N=52(24.5 \%)\end{array}$ \\
\hline
\end{tabular}

In Ebrahimi-Fakhari et al. [54] fever in $78 \%$ of patients, peritonitis symptoms in $95 \%$, pleuritis in 59\%, arthritis in $32 \%$, arthralgia in $60 \%$, erysipelas-like skin rash in $23 \%$, vasculitis in $8 \%$ have been reported.

In Dundar's [37] report $49.6 \%$ of patients had no MEFV mutations, $26.41 \%$ were heterozygous, $15.29 \%$ were compound, and $8.60 \%$ were homozygous mutation. In Balci et al. [55], Esmaeili et al. [41], and Bonyadi et al. [40] case series results have been shown in Table 4 . Comparison of this study with different ethnic groups has been presented in Table 5.

The genetic expression of this study is similar to Arabs and somewhat to Armenians.

In this study, the common combined heterozygous mutation was M694V-V726A with 10.46\%, M694V-M694V with $7.1 \%$, and M680I-V726A with $6.27 \%$. The most common genotype of patients was M694V-M694V in different studies $[38,40,41]$; this genotype was in second rate of our results.

In this study M694V mutation with $18.3 \%$ and compound mutation V726A-M694V with $12.7 \%$ were common mutations in male, while M694V mutation with $24.5 \%$ and M694V-M694V with $10.7 \%$ were the common genotype in female. The sexual genotype difference has not been mentioned in certain studies.

Rare mutations were observed in this study such as K695R and F479L with $0.2 \%$ frequency. In Manna et al. report [53] 
TABLE 4: Comparison of different genotypes studies.

\begin{tabular}{lccccc}
\hline \multirow{2}{*}{ Studies } & \multicolumn{5}{c}{ Mutations frequencies (\%) } \\
& M694V & V726A & M680I & M694I & E148Q \\
\hline Dundar et al. [37] & 68.14 & 76.4 & 62.7 & 0.46 & 15.5 \\
Yilmaz et al. [38] & 55 & 3 & 16 & 0 & 10 \\
Ben-Chetrit et al. [39] & 38 & 4 & 8 & 0 & 4 \\
Bonyadi et al. [40] & 42.4 & 17 & 15.2 & 2.2 & 16.2 \\
Esmaeili et al. [41] & 28 & 9 & 7 & 1 & 7 \\
Our study & 20.9 & 12.7 & 10.3 & 2.1 & 10.7 \\
\hline
\end{tabular}

TABLE 5: Comparison of different ethnics' studies.

\begin{tabular}{lccccc}
\hline Ethnic groups & M694V & V726A & M680I & M694I & E148Q \\
\hline Jews [39, 42, 43] & 77 & 12.3 & 0.6 & 0 & 10.2 \\
Armenians [44, 45] & 52 & 26 & 20 & 0.2 & 1.8 \\
Arabs [46-48] & 42.5 & 23.1 & 9.6 & 14.1 & 10.7 \\
Turks [49-51] & 71.3 & 8.5 & 15 & 1.7 & 3.5 \\
Iranian, Azeri Turks [41] & 54 & 16.7 & 12.6 & 2.5 & 14.2 \\
Our study & 20.9 & 12.7 & 10.3 & 2.1 & 10.7 \\
\hline
\end{tabular}

rare mutations were K695R with 0.67\%, M694I with 1.04\%, and $\mathrm{R} 761 \mathrm{H}$ with $1.91 \%$. In Yilmaz study [38] the R761S in 1\% and V726A in $3 \%$ of patients were rare mutations.

The Bonyadi study [56] showed these rare mutations: $\mathrm{A} 744 \mathrm{~S}$ in $0.5 \%$, M694I in $2.2 \%, \mathrm{~F} 479 \mathrm{~L}$ in $1.3 \%, \mathrm{P} 369 \mathrm{~S}$ in $1.3 \%$, E167D in $1.2 \%$, and R408Q in $1.2 \%$.

In our study there was one case of amyloidosis who presented with resistant nephrotic syndrome and M694IM694I mutations.

Some studies have shown that the M694V mutation is associated with a severe form of the disease [55]. Kincir et al. showed that arthritis and abdominal pain accompany mutations M694V and E148Q [57].

This study showed that M694V-M694V mutations are more common in patients with presentation during first decade of life, while in those with disease presentation during second decade or later genotype V726A-M694V was common. Patients with homozygous mutation M694V have lower age at onset [16].

In our study two patients presented with the complaint of recurrent orchitis and compound heterozygous mutations M694V-V726A and M694V-E148Q, and two female siblings had massive ascites, abdominal pain, and idiopathic hepatitis with homozygous mutation M697V; this association has been reported in the literature [2].

\section{Conclusion}

This study showed that first decade of life is the most common age in disease presentation of FMF; abdominal pain is the main symptom; M694V and M694V-V726A are the most common alleles and compound genotype. M694V-M694V genotype is associated with lower age presentation and joint involvement. Our genotype is similar to Arabs and in some way Armenians and erysipelas-like skin rash is not common feature in our patients.

\section{Conflict of Interests}

The author declares that there is no conflict of interests regarding the publication of this paper.

\section{References}

[1] M. Medlej-Hashim, V. Delague, E. Chouery et al., "Amyloidosis in familial Mediterranean fever patients: correlation with $M E F V$ genotype and SAA1 and MICA polymorphisms effects," BMC Medical Genetics, vol. 5, article 4, 2004.

[2] M. Shohat and G. J. Halpern, "Familial Mediterranean fever-a review," Genetics in Medicine, vol. 13, no. 6, pp. 487-498, 2011.

[3] M. Medlej-Hashim, J. Loiselet, G. Lefranc, and A. Mégarbané, "Familial Mediterranean Fever (FMF): from diagnosis to treatment," Santé, vol. 14, no. 4, pp. 261-266, 2004.

[4] M. L. H. Rubio, C. D. Beltrán, and C. A. Ramírez, "Autoinflammatory disorders: a new concept in hereditary periodic fever syndromes," Anales de Medicina Interna, vol. 21, no. 3, pp. 143147, 2004.

[5] P. Fietta, "AutoInflammatory disease: the hereditary periodic fever syndromes," Acta Biomedica, vol. 75, no. 2, pp. 92-99, 2004.

[6] F. Salehzadeh, D. Emami, A. A. Zolfegari et al., "Familial Mediterranean fever in northwest of Iran (Ardabil): the first global report from Iran," Turkish Journal of Pediatrics, vol. 50, no. 1, pp. 40-44, 2008.

[7] J. Meyerhoff, "Familial Mediterranean fever: report of a large family, review of the literature, and discussion of the frequency of amyloidosis," Medicine, vol. 59, no. 1, pp. 66-77, 1980.

[8] M. Aringer, "Periodic fever syndromes-a clinical overview," Acta Medica Austriaca, vol. 31, no. 1, pp. 8-12, 2004.

[9] E. Ben-Chetrit and M. Levy, "Familial mediterranean fever," The Lancet, vol. 351, no. 9103, pp. 659-664, 1998.

[10] S. Savic, L. J. Dickie, M. Battellino, and M. F. McDermott, "Familial mediterranean fever and related periodic fever syndromes/autoinflammatory diseases," Current Opinion in Rheumatology, vol. 24, no. 1, pp. 103-112, 2012.

[11] An online database for autoinflammatory mutations, http://fmf .igh.cnrs.fr/ISSAID/infevers.

[12] R. Brik, M. Shinawi, I. Kepten, M. Berant, and R. GershoniBaruch, "Familial Mediterranean fever: clinical and genetic characterization in a mixed pediatric population of Jewish and Arab patients," Pediatrics, vol. 103, no. 5, article e70, 1999.

[13] E. Ben-Chetrit, "Familial Mediterranean fever (FMF) and renal AA amyloidosis-phenotype-genotype correlation, treatment and prognosis," Journal of Nephrology, vol. 16, no. 3, pp. 431-434, 2003.

[14] M. Lidar, R. Kedem, A. Mor, D. Levartovsky, P. Langevitz, and A. Livneh, "Arthritis as the sole episodic manifestation of familial Mediterranean fever," Journal of Rheumatology, vol. 32, no. 5, pp. 859-862, 2005.

[15] H. Bodur, H. Uçan, S. Seçkin, Ü. Seçkin, and O. H. Gündüz, "Protracted familial Mediterranean fever arthritis," Rheumatology International, vol. 19, no. 1-2, pp. 71-73, 1999.

[16] M. Tunca, S. Akar, F. Onen et al., "Familial Mediterranean fever (FMF) in Turkey: results of a nationwide multicenter study," Medicine, vol. 84, pp. 1-11, 2005.

[17] H. A. Majeed, A. K. Al-Qudah, H. Qubain, and H. M. Shahin, "The clinical patterns of myalgia in children with familial 
Mediterranean fever," Seminars in Arthritis and Rheumatism, vol. 30, no. 2, pp. 138-143, 2000.

[18] A. Soylu, B. Kasap, M. Türkmen, G. S. Saylam, and S. Kavukçu, "Febrile myalgia syndrome in familial Mediterranean fever," Journal of Clinical Rheumatology, vol. 12, no. 2, pp. 93-96, 2006.

[19] G. Sidi, Y. Shinar, A. Livneh, P. Langevitz, M. Pras, and E. Pras, "Protracted febrile myalgia of familial Mediterranean fever. Mutation analysis and clinical correlations," Scandinavian Journal of Rheumatology, vol. 29, no. 3, pp. 174-176, 2000.

[20] J. Ten Oever and D. R. A. J. de Munck, "Recurrent pleurisy as sole manifestation of familial Mediterranean fever," Nederlands Tijdschrift voor Geneeskunde, vol. 152, no. 15, pp. 887-890, 2008.

[21] A. Y. Gasparyan and A. H. Petrosyan, "Cardiac involvement in familial Mediterranean fever," Cardiovascular Therapy and Prevention, vol. 6, no. 6, pp. 117-124, 2007.

[22] A. Dabestani, L. M. Noble, J. S. Child, J. Krivokapich, and A. D. Schwabe, "Pericardial disease in familial Mediterranean fever: an echocardiographic study," CHEST Journal, vol. 81, no. 5, pp. 592-595, 1982.

[23] İ. Sarı, M. Birlik, and T. Kasifoğlu, "Familial Mediterranean fever: an updated review," Europen Journal of Rheumatology, vol. 1, no. 1, pp. 21-33, 2014.

[24] T. Akpolat, I. Akpolat, F. Karagoz, E. Yilmaz, B. Kandemir, and S. Ozen, "Familial Mediterranean fever and glomerulonephritis and review of the literature," Rheumatology International, vol. 24, no. 1, pp. 43-45, 2004.

[25] A. Barzilai, P. Langeritz, I. Goldberg et al., "Erysipelas-like erythema of familial mediterranean fever: clinicopathologic correlation," Journal of the American Academy of Dermatology, vol. 42, no. 5, part 1, pp. 791-795, 2000.

[26] H. A. Majeed, K. Ghandour, and H. M. Shahin, "The Acute Scrotum in Arab children with familial Mediterranean fever," Pediatric Surgery International, vol. 16, no. 1-2, pp. 72-74, 2000.

[27] A. Zayed, H. Nabil, O. State, and A. Badawy, "Subfertility in women with familial Mediterranean fever," Journal of Obstetrics and Gynaecology Research, vol. 38, no. 10, pp. 1240-1244, 2012.

[28] E. Ben-Chetrit and M. Levy, "Reproductive system in familial Mediterranean fever: an overview," Annals of the Rheumatic Diseases, vol. 62, no. 10, pp. 916-919, 2003.

[29] J. Vilaseca, J. Tor, J. Guardia, and R. Bacardi, "Periodic meningitis and familial Mediterranean fever," Archives of Internal Medicine, vol. 142, no. 2, pp. 378-379, 1982.

[30] K. Aksu and G. Keser, "Coexistence of vasculitides with Familial Mediterranean Fever," Rheumatology International, vol. 31, no. 10, pp. 1263-1274, 2011.

[31] G. Ceylan, S. Erten, and K. Ercan, "Co-existence of familial Mediterranean fever and multiple sclerosis in two patients," Acta Reumatológica Portuguesa, vol. 244, no. 1-2, pp. 21-28, 2014.

[32] A. Unal, A. Dursun, U. Emre, N. F. Tascilar, and H. Ankarali, "Evaluation of common mutations in the Mediterranean fever gene in Multiple Sclerosis patients: is it a susceptibility gene?" Journal of the Neurological Sciences, vol. 294, no. 1-2, pp. 38-42, 2010.

[33] D. Cattan, C. Notarnicola, N. Molinari, and I. Touitou, "Inflammatory bowel disease in non-Ashkenazi Jews with familial Mediterranean fever," The Lancet, vol. 355, no. 9201, pp. 378-379, 2000.

[34] Ö. F. Beşer, Ö. Kasapçopur, F. Ç. Çokuğraş, T. Kutlu, N. Arsoy, and T. Erkan, "Association of inflammatory bowel disease with familial mediterranean fever in Turkish children," Journal of Pediatric Gastroenterology and Nutrition, vol. 56, no. 5, pp. 498502, 2013.
[35] C. Deltas, F. Kanakoudi, and J. Pratsidou, "Familial Mediterranean fever," Rheumatology International, vol. 18, no. 5-6, p. 70, 2000.

[36] S. Padeh, "Periodic fever syndromes," Pediatric Clinics of North America, vol. 52, no. 2, pp. 577-609, 2005.

[37] M. Dundar, E. F. Emirogullari, A. Kiraz, S. Taheri, and M. Baskol, "Common familial Mediterranean fever gene mutations in a Turkish cohort," Molecular Biology Reports, vol. 38, no. 8, pp. 5065-5069, 2011.

[38] R. Yilmaz, S. Ozer, H. Ozyurt, U. Erkorkmaz, and S. Sahin, "Familial Mediterranean fever gene mutations in the inner northern region of Turkey and genotype-phenotype correlation in children," Journal of Paediatrics and Child Health, vol. 45, no. 11, pp. 641-645, 2009.

[39] E. Ben-Chetrit, I. Lerer, E. Malamud, C. Domingo, and D. Abeliovich, "The E148Q mutation in the MEFV gene: is it a disease-causing mutation or a sequence variant?" Human Mutation, vol. 15, no. 4, pp. 385-386, 2000.

[40] M. Bonyadi, M. Esmaeili, A. Karimi, and S. Dastgiri, "Common mediterranean fever gene mutations in the Azeri Turkish population of Iran," Genetic Testing and Molecular Biomarkers, vol. 14, no. 1, pp. 149-151, 2010.

[41] M. Esmaeili, M. Bonyadi, M. Rafeey, K. Sakha, and M. H. Somi, "Common MEFV mutation analysi in Iranian Azeri Turkish patient with Familial Mediterranean fever," Seminars in Arthritis and Rheumatism, vol. 37, no. 5, pp. 334-338, 2008.

[42] E. Ben-Chetrit, S. Urieli-Shoval, S. Calko, D. Abeliovich, and Y. Matzner, "Molecular diagnosis of FMF: lessons from a study of 446 unrelated individuals," Clinical and Experimental Rheumatology, vol. 20, no. 4, pp. S25-S29, 2002.

[43] C. Dodé, C. Pêcheux, C. Cazeneuve et al., "Mutations in the $M E F V$ gene in a large series of patients with a clinical diagnosis of familial mediterranean fever," American Journal of Medical Genetics, vol. 92, no. 4, pp. 241-246, 2000.

[44] T. Sarkisian, H. Ajrapetyan, and G. Shahsuvaryan, "Molecular study of FMF patients in Armenia," Current Drug TargetsInflammation \& Allergy, vol. 4, no. 1, pp. 113-116, 2005.

[45] C. Cazeneuve, T. Sarkisian, C. Pêcheux et al., "MEFV-gene analysis in Armenian patients with familial Mediterranean fever: diagnostic value and unfavorable renal prognosis of the M694V homozygous genotype-genetic and therapeutic implications," The American Journal of Human Genetics, vol. 65, no. 1, pp. 88-97, 1999.

[46] H. A. Mjeed, M. El-Khateeb, H. El-Shanti, Z. Abu Rabaiha, M. Tayeh, and D. Najib, "The spectrum of familial Mediterrenean fever gene mutation in Arabs: report of a larg series," Seminars in Arthritis and Rheumatism, vol. 34, pp. 813-818, 2005.

[47] H. Mattit, M. Joma, S. Al-Cheikh et al., "Familial Mediterranean fever in the Syrian population: gene mutation frequencies, carrier rates and phenotype-genotype correlation," European Journal of Medical Genetics, vol. 49, no. 6, pp. 481-486, 2006.

[48] M. Medlej-Hashim, J.-L. Serre, S. Corbani et al., "Familial Mediterranean fever (FMF) in Lebanon and Jordan: a population genetics study and report of three novel mutations," European Journal of Medical Genetics, vol. 48, no. 4, pp. 412420, 2005.

[49] N. Akar, M. Misiroglu, F. Yalcnkaya et al., "MEFV mutations in Turkish patients suffering from familial Mediterranean fever," Human Mutation, vol. 15, no. 1, pp. 118-119, 2000.

[50] E. Yilmaz, S. Ozen, B. Balci et al., "Mutation frequency of familial Mediterranean fever and evidence for a high carrier 
rate in the Turkish population," European Journal of Human Genetics, vol. 9, no. 7, pp. 553-555, 2001.

[51] V. Ertekin, M. A. Selimoǧlu, and I. Pirim, "Familial Mediterranean fever in a childhood population in eastern Turkey," Pediatrics International, vol. 47, no. 6, pp. 640-644, 2005.

[52] C. Sackesen, A. Bakkaloglu, B. E. Sekerel et al., "Decreased prevalence of atopy in paediatric patients with familial Mediterranean fever," Annals of the Rheumatic Diseases, vol. 63, no. 2, pp. 187-190, 2004.

[53] R. Manna, C. Cerquaglia, V. Curigliano et al., "Clinical features of familial Mediterranean fever: an Italian overview," European Review for Medical and Pharmacological Sciences, vol. 13, supplement 1, pp. 51-53, 2009.

[54] D. Ebrahimi-Fakhari, S. O. Schönland, U. Hegenbart et al., "Familial Mediterranean fever in Germany: clinical presentation and amyloidosis risk," Scandinavian Journal of Rheumatology, vol. 42, no. 1, pp. 52-58, 2013.

[55] B. Balci, K. Tinaztepe, E. Yilmaz et al., "MEFV gene mutations in familial Mediterranean fever phenotype II patients with renal amyloidosis in childhood: a retrospective clinicopathological and molecular study," Nephrology Dialysis Transplantation, vol. 17, no. 11, pp. 1921-1923, 2002.

[56] M. Bonyadi, M. Esmaeili, H. Jalali et al., "MEFV mutations in Iranian Azeri Turkish patients with familial Mediterranean fever," Clinical Genetics, vol. 76, no. 5, pp. 477-480, 2009.

[57] M. Kincir, F. Duksal, O. Cevit et al., "Association of clinical and genetic features in familial Mediterranean fever among children from central Anatolia, Turkey," Proceedings of the National Academy of Sciences, India Section B: Biological Sciences, vol. 85, no. 3, pp. 793-800, 2015. 


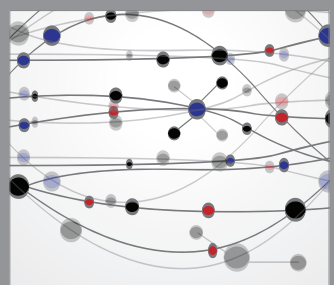

The Scientific World Journal
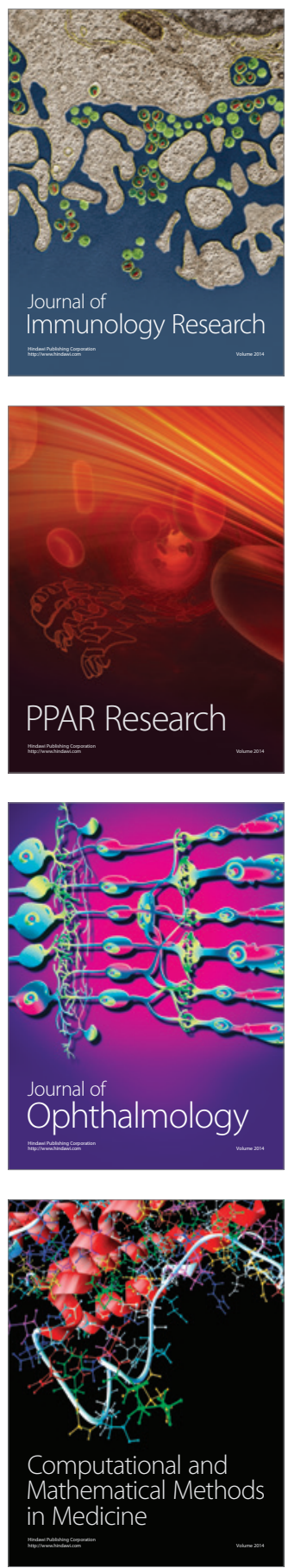

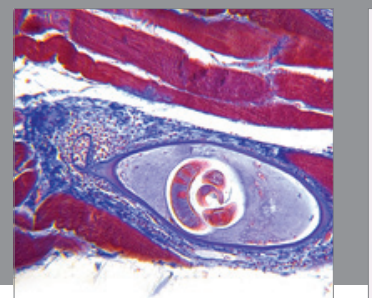

Gastroenterology

Research and Practice
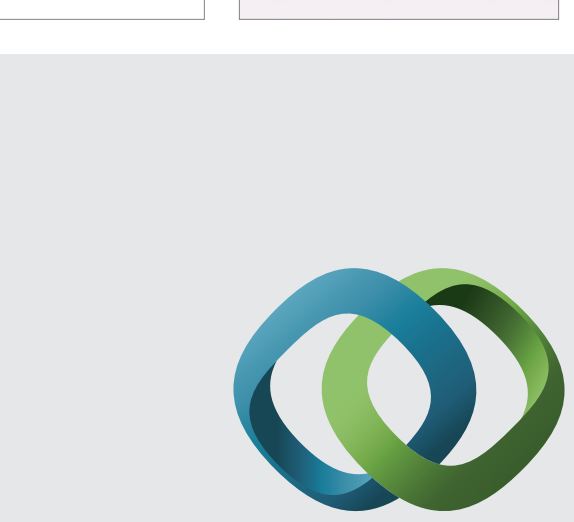

\section{Hindawi}

Submit your manuscripts at

http://www.hindawi.com
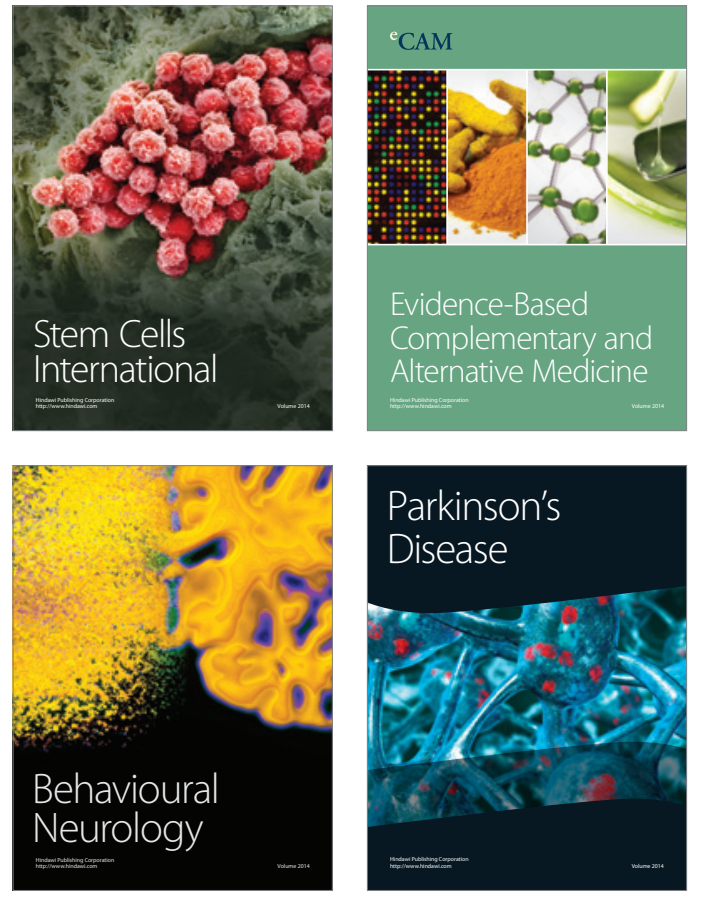
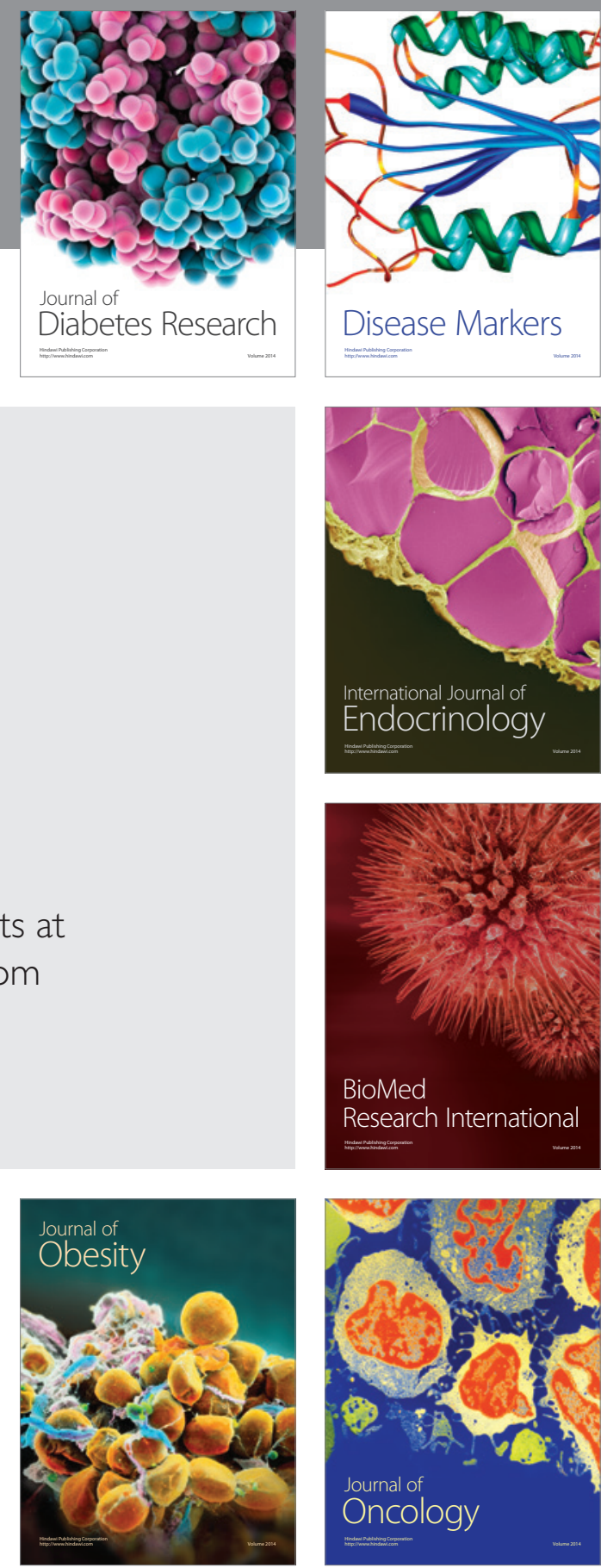

Disease Markers
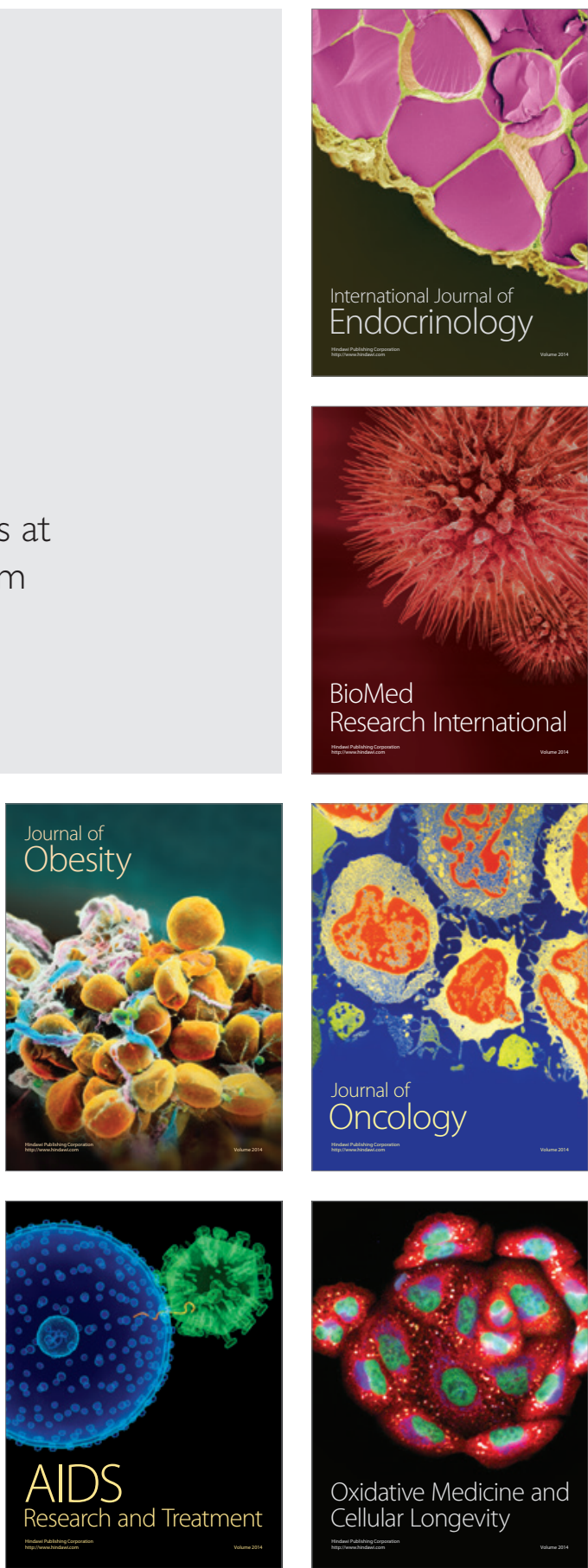